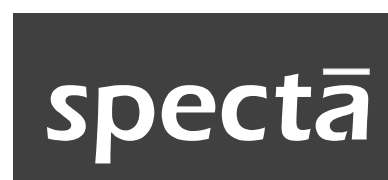

Journal of Photography,

Arts, and Media

Volume 1 Nomor 1,
Mei 2017: $31-50$

\section{ANALISIS SEMIOTIKA PENGGUNAAN ESTETIKA FOTO POTRET DALAM KARYA SENI STENSIL DIGIE SIGIT}

\author{
Fahla Fadhillah Lotan \\ Edial Rusli* \\ Adya Arsita** \\ Fakultas Seni Media Rekam, Institut Seni Indonesia (ISI) Yogyakarta \\ Surel: edial_rusli@yahoo.com
}

\begin{abstract}
Abstrak
Penelitian ini bertujuan untuk mengetahui bagaimana foto potret digunakan sebagai media pencipta visual dalam proses pembuatan karya seni stensil dari seniman Digie Sigit. Metode penelitian yang digunakan adalah metode penelitian kualitatif menggunakan pendekatan estetika kemudian dianalisis secara semiotika yang mengkaji tanda-tanda visual yang merujuk pada teori denotasi dan konotasi. Analisis data dalam penelitian ini berupa penjelasan deskriptif yang bersifat eksploratif untuk menggambarkan dan menjelaskan suatu fenomena. Uji validitas data yang digunakan adalah triangulasi data (data triangulations) dengan wawancara terhadap objek yang diteliti dan bisa dipercaya. Berdasarkan analisis data dijelaskan bahwa seni stensil dari Digie Sigit memiliki muatan makna penting yang diutarakannya dengan menggunakan visual sebagai ingatan pada masyarakat. Digie Sigit menggunakan media seni stensil yang berawal dari olah fotografi sebagai metode propaganda yang paling mudah untuk menyasar publik secara luas. Perubahan foto potret secara bentuk yang akhirnya menjadi karya seni grafis memberikan pengaruh dalam tataran metode aplikasi fotografi. Hal tersebut menjadi tambahan pengetahuan tentang aplikasi fotografi yang juga mampu memasuki ranah seni lain selain seni media rekam. Tataran makna yang terkandung dalam karya-karya seni stensil dari Digie Sigit, kekuatan pengaruh tanda-tanda visual menjurus pada denotasi akan karyanya yang diterjemahkan secara konotasi terkait dengan isyarat yang ditampilkannya secara visual sebagai sebuah kritik sosial.
\end{abstract}

Kata Kunci : semiotika, estetika, foto potret, seni stensil

\begin{abstract}
Semiotics Analysis for the Aesthetics of Portrait Photographs in Digie Sigit's Stencil Artworks. The research titled aims to find out how portrait photographs are used as visual media in the process of making stencil art by Digie Sigit The research method used is qualitative research method using the aesthetics approach and then analyzed in semiotics which examines visual signs referring to the theory of denotation and connotation. Data analysis in this research is an explanatory of descriptive explanation to describe and to explain a phenomenon. The data validity test used is triangulation of data (data triangulations), based on the interviews with the reliable object. Based on the data analysis, it is explained that the stencil art of Digie Sigit has an important significance expressed by using visuals as the memory of the society. Digie Sigit uses stencil art media originated from photography as the easiest propaganda method to target the public widely. Portrait photograph eventually shifts functions and becomes the work of graphic art that gives influence in the level of photography application method. It becomes an extended knowledge about photography applications that also able to enter the realm of art other than recorded media art. Meaning conveyed in Digie Sigit's stencil artworks, the influence of visual signs lead to denotation meaning on his artworks which is translated in connotation associated with visually displayed cues an instrument of social criticism.
\end{abstract}

Keywords: semiotics, aesthetics, portrait photography, stencil art

\footnotetext{
*Dosen di Program Studi Fotografi, Jurusan Fotografi, Fakultas Seni Media Rekam, ISI Yogyakarta

${ }^{* *}$ Dosen di Program Studi Fotografi, Jurusan Fotografi, Fakultas Seni Media Rekam, ISI Yogyakarta
} 


\section{PENDAHULUAN}

Pada dunia seni urban, seni jalanan merupakan satu dari sekian hal yang menjadi cukup dominan di kota Yogyakarta dalam 15 tahun ini. Maraknya kegiatan seni jalanan di Yogyakarta berawal di tahun 2000 yang merupakan perkembangan dari seni grafiti. Kata "jalanan" pada seni jalanan mengandung arti tanpa aturan, vandal atau ilegal, menangmenangan (Barry, 2008: 19). Penempatan yang tanpa ijin merupakan ciri khas seni ini. Kedekatan penulis dengan seni jalanan dan dengan latar belakang pendidikan fotografi memberikan peluang besar untuk melakukan penelitian dan pengkajian beberapa hal yang berada di antaranya, yaitu fotografi dan seni jalanan.

Salah satu hal yang menjadi menarik untuk disimak melalui perspektif bidang fotografi adalah seni stensil yang juga merupakan satu dari sekian banyak gaya penerapan dalam seni jalanan. Fotografi yang sangat terbiasa dengan detail sebuah objek hingga jatuhnya cahaya pada bidang tertentu juga hadir dalam proses kekaryaan di dunia seni stensil (Sigit, 2013 : 7).

Sebagai media mutakhir di abad XIX, fotografi telah dimanfaatkan sebagai sarana pengabadian objek hingga peristiwa. Sejak adanya fotografi, manusia semakin dipermudah praktiknya dalam membuat sebuah imaji yang serupa dengan aslinya (Irwandi \& M. Fajar Apriyanto, 2012: 1). Kemudahankemudahan tersebut dimanfaatkan untuk berbagai perkembangan seni visual hingga seni terapan seperti periklanan dan bentukbentuk propaganda sosial-politik. Salah satunya, dalam dunia seni rupa terdapat sebuah aksi seni publik yang dinamakan seni jalanan. Seni jalanan masuk dalam koridor seni urban yang mana banyak membahas tentang isuisu keseharian, permasalahan kota, ekonomi, hingga pendidikan dan sosial-politik.

\section{Dalam "Membaca Fotografi Potret"} (2012: 5-6), Irwandi \& M. Fajar Apriyanto menjelaskan bahwa ada empat hal penting yang ditonjolkan, yaitu : (1) penonjolan kepribadian/ personality, (2) penggunaan pencahayaan efektif, (3) latar belakang, dan (4) pose subjek.

Di kota Yogyakarta terdapat 5 pelaku seni stensil. Para pelaku tersebut ialah Anagard, Medialegal, Guerillas, Whattobedone, dan DS. Dari 5 pelaku tersebut, 4 diantaranya menggunakan media fotografi dalam proses pembuatan stensilnya. Pelaku seni stensil yang tidak menggunakan fotografi secara langsung adalah Anagard. Berbeda dengan 4 pelaku lainnya, Anagard menjadikan fotografi sebagai media peninjau jatuhnya bayangan pada objek saja. Digie Sigit memiliki keunikan di antara 4 pelaku stensil lainnya yaitu pemanfaatan foto potret yang dibuatnya terlebih dahulu. Terlihat dari beberapa karyanya yang telah didistribusikan di sudut-sudut ruang publik bahwa visual yang ditampilkan dalam karya seni stensilnya sangat kuat akan kesan realis yang dimiliki oleh fotografi.

Penelitian ini akan difokuskan pada Digie Sigit atau dikenal juga dengan nama alias DS. Digie Sigit adalah seorang seniman stensil dan rapper dari sebuah kelompok musik rap Yogyakarta yaitu Technoshit. Digie Sigit mengawali kegiatan berkeseniannya dengan aktif memotret kejadian-kejadian di sekitar yang berhubungan dengan sosial dan politik. Stensil dari Digie Sigit berbicara pada masyarakat dengan tujuan mengingatkan dampak negatif kapitalis, permasalahan politik atau hilangnya tradisi budaya.

Digie Sigit memiliki ketertarikan dengan fotografi jurnalistik sejak awal. Dalam aksi jalanannya, Digie Sigit menggunakan nama alias DS yang diikuti dengan angka di belakangnya sesuai dengan tahun produksi karya tersebut, misalnya DS11 yaitu karya Digie Sigit pada tahun 2011, dan begitupun 
selanjutnya hingga nama alias tersebut sempat berganti sementara menjadi Tirolesia. Tirolesia adalah nama alias yang dipakai Digie sebagai perwujudan hasil residensinya selama tiga bulan di Tirol, sebuah desa kecil di Austria pada tahun 2014 lalu. Kemudian dibuatlah nama alias Tirolesia yang berarti Tirol dan Indonesia. ${ }^{1}$ Dalam seri Tirolesia, Digie Sigit lebih banyak melakukan ekspos terhadap figur-figur yang ditemuinya selama berada di desa Tirol, Austria.

Penulis memfokuskan penelitian pada karya-karyanya dalam beberapa seri DS dan 2 karya dalam seri Tirolesia dikarenakan kecenderungan kekuatan fotografi memengaruhi karyanya pada seri-seri tersebut. Kajian ini akan menggunakan pendekatan estetika pada foto potret dan mengkajinya menggunakan analisis denotasi dan konotasi semiotika pada hasil olahannya yang telah menjadi bentuk stensil dan banyak mengisyaratkan makna dari berbagai hal.

Dalam beberapa karya Digie Sigit pada seri DS12, DS13, DS15 hingga seri rangkaian karya Tirolesianya, posisi fotografi berada pada lapisan terpenting dalam pembetuk visualnya, maka pada penelitian ini penulis memilih 5 karya dari setiap seri yang disebutkan sebelumnya.

Kecenderungan tersebut sangat berpotensi sebagai media penelitian akan penggunaan fotografi khususnya potret terhadap karyakarya stensil Digie Sigit. Selain beberapa hal di atas, kajian tentang fotografi yang berhubungan dengan seni lain, dalam hal ini menggabungkan keduanya yaitu fotografi dan seni jalanan masih sangat minim. Pergerakan seni jalanan khususnya di kota Yogyakarta sangat mendominasi pergerakan di antara anak-anak muda yang ingin menyuarakan kritik, protes, eksistensi, hingga luapan ekspresi seni yang cakupannya menjadi sangat luas dikarenakan sasaran audiens di sini tertuju

${ }^{1}$ Diambil dari pertemuan langsung bersama Digie Sigit dalam Artist Talk pameran Tirolesia di iCan pada 20 Februari 2015, pukul 17.54. pada khalayak umum tanpa membedakan status sosialnya.

Topik penelitian ini dirasakan menjadi menarik karena sejauh ini, pembahasan tentang penggunaan fotografi terhadap aktifitas seni jalanan belum pernah dilakukan oleh peneliti sebelumnya. Penelitian-penelitian terdahulu belum sampai menyentuh aspekaspek fotografi dan analisis kecenderungan penggunaan fotografi terhadap karya-karya stensil khususnya. Melihat hal tersebut, dalam upaya memerkaya khasanah wacana fotografi dan seni jalanan, maka penelitian ini menjadi sangat penting.

Selain beberapa hal yang telah dipaparkan penulis, hal lain yang menarik bagi penulis secara pribadi untuk melakukan penelitian ini adalah rasa ingin tahu mengenai perkembangan fotografi yang dapat diaplikasikan lebih mudah saat dijadikan media propaganda di ruang publik. Ada beberapa gerakan seni jalanan yang menggunakan media fotografi namun hal tersebut lebih banyak dilakukan di beberapa negara selain Indonesia, contohnya pergerakan seni jalanan di kota Berlin, London, dan beberapa negara Amerika. Fotografi yang diaplikasikan di jalan sebagai media alternatif dalam seni jalanan memiliki daya tarik yang lebih dikarenakan fotografi yang realitasnya sangat kuat dan mampu membangkitkan ingatan audiens saat berhadapan langsung.

Aksi seni jalanan yang sangat kuat di kota Yogyakarta khususnya yang mempunyai banyak peluang untuk melakukan aksi responsif terhadap keadaan tata ruang kota, hingga isu-isu yang berkembang di antaranya. Dikarenakan fotografi yang bersifat mampu merekam realitas dan memuat segala hal yang ada dalam realitas di dunia yang mampu direkamnya secara sempurna, maka fotografi menghadirkan realitas yang meniadakan jarak bagi publik yang menyimak realitas. Tidak saja hanya realitas empirik yang mampu dihadirkan, melainkan gagasan-gagasan 
perupaan serumit apa pun direpresentasikan dengan baik (Svarajati, 2013: 12-13).

\section{METODE PENELITIAN}

Penelitian ini menggunakan metode kualitatif yaitu prosedur penelitian untuk menghasilkan data deskripsi berupa katakata atau lisan dari orang atau perilaku yang diamati seperti dikatakan oleh Meleon (1995: 13). Penelitian Kualitatif juga diartikan sebagai penelitian yang bersifat pemahaman dan memprediksikan atau mengontrol, dimana dalam penelitian ini temuannya tidak didasarkan kepada prosedur statistik atau bentuk hitungan lainnya (Corbin, 2003 : 4). Dalam metode penelitian kualitatif, penelitian ini juga disertai dengan tipe deskriptif, sedangkan tipe penelitian dengan deskriptif yaitu peneliti mendeskripsikan atau mengonstruksi dari teori yang ada terhadap subjek penelitian.

Estetika dalam fotografi yang mampu dimanfaatkan dalam proses pembentukan seni stensil meliputi cahaya, nada, bayangan, bentuk, dan perspektif. Elemen-elemen visual yang dihadirkan dalam foto potret yang dibuat oleh Digie Sigit sebagai bahan olahan seni stensilnya dikaitkan penulis pada teori Markowski dalam The Art of Photography (1984) terhadap elemen penting pembangun sebuah foto yang kemudian akan berdampak pada citra keindahan foto tersebut.

Selain teori estetika, penggunaan teori semiotika dalam pengkajian ini merupakan metode untuk melakukan kajian terhadap simbol-simbol visual fotografi yang terdapat pada foto potret sebelum dilakukan pengolahan menjadi karya stensil. Penggunaan fotografi pada proses pembentukan visual dalam stensil Digie Sigit memiliki muatan kuat pada konsep dan gagasan yang disampaikannya, terutama dengan dilengkapi oleh pengikutsertaan Reyna (puteri tunggalnya) pada beberapa seri yang dibuat Digie Sigit tentunya akan memiliki potensi menarik untuk dianalisis dengan denotasi dan konotasi dalam semiotika.

Istilah 'konotasi' digunakan untuk merujuk pada asosiasi 'pribadi' (ideologi, emosional, dll.) sosial budaya dan tanda, yang biasanya berhubungan dengan penafsir kelas, usia, jenis kelamin, etnis dan sebagainya. Tanda lebih terbuka untuk interpretasi sedangkan denotasi kadang-kadang dianggap sebagai kode digital dan konotasi sebagai kode analog (Wilden, 1987: 224). Pada tataran estetika, Digie Sigit menerapkannya dalam karyanya yang kuat akan aspek ideasional dan citra figur, hingga makna dari tandatanda visual terkait dapat terhubung dengan aspek ideasional yang terdapat dalam sisi estetika yang ditampilkannya.

Dikarenakan pada penelitian ini Digie Sigit membuat sekaligus menggunakan potret yang dibuatnya untuk kemudian dijadikan karya stensil, apabila dianalisis dengan semiotika makan dalam fotografi terdapat prosedurprosedur untuk menemukan makna konotasi di dalam sebuah potret. Enam prosedur yang berpotensi membantu menganalisis makna konotasi dalam foto potret, yaitu: (1) trick effect, yaitu memanfaatkan teknik olah imaji secara digital; (2) pose, hal yang berkaitan dengan mengatur arah pandang objek yang dipotret; (3) object, dengan menggunakan seleksi, penataan, dan pemilihan sudut pandang pemotretan; (4) fotogenia, hal-hal yang berkaitan dengan cara mengatur exposure, lighting, dan sebagainya; (5) estetisme, dengan menerapkan teknik posterisasi, hal tersebut sangat berhubungan dengan pola kerja yang dilakukan Digie Sigit dalam mengolah potret menjadi seni stensil; (6) sintaksis, yaitu dengan menampilkan beberapa foto sekaligusdalam bentuk sekuenssehingga penanda dan petanda konotasinya tidak ditemukan korelasinya jika foto tersebut disajikan secara terpisah (Sunardi, 2002: 173-175). 


\section{PEMBAHASAN}

\section{Fotografi Potret dan Estetika Fotografi}

Pada awal kemunculan fotografi potret, sejarah mencatat bahwa model-model dengan pose kaku dan datar seringkali mendominasi pada jaman tersebut. Sebagian besar foto-foto potret yang dihadirkan sebelum tahun 1860 belum menampakkan nilai-nilai ideasionalnya, atau dapat dikatakan sebagai hasil teknikal fotografernya saja. Pembubuhan konsep dan ide seakan tidak begitu dibutuhkan pada era tersebut, merekam identitas menjadi sebuah faktor terpenting.

Di Indonesia, jika membahas hal-hal yang berkaitan dengan fotografi potret jelas akan terhubung dengan Kasian Cephas, seorang pelaku fotografi potret yang hampir keseluruhan karyanya mampu menceritakan suasana kerajaan jaman dahulu. Kekuatan fotografi yang tidak dimiliki oleh bidangbidang seni lain adalah memberikan peluang terhadap audiens untuk memasuki ingatan melalui simbol-simbol, gestur, pose, hingga suasana yang direkam dalam karya fotografi. Masuknya fotografi ke Indonesia pada abad XIX, secara langsung memperkenalkan fotografi potret pada masyarakat Indonesia. Pada awal dikenalnya fotografi potret dalam negeri, banyak digunakan untuk memotret kehidupan kerajaan dan keluarganya, di situ pula dapat terlihat status sosial yang dicitrakan melalui fotografi potret. Karena, pada saat dilakukan pemotretan bagi kerajaan, penataan tempat hingga latar belakangnya sangat diperhitungkan untuk sebuah citra yang tinggi dan berwibawa.

Dalam "Membaca Fotografi Potret"(2012: 8-10) dijelaskan oleh Irwandi \& Apriyanto bahwa unsur-unsur yang terdapat pada fotografi potret dapat dilihat dari:

\section{Pose}

Pose merupakan sebuah posisi objek yang akan berhubungan dengan karakter apa yang akan ditampilkan dalam sebuah karya fotografi. Pose wajah dan badan secara garis besar dibagi menjadi dua, yaitu posisi en face (wajah menghadap kamera) dan en profile (wajah dipalingkan $90^{\circ}$ terhadap kamera), menurut Charpentier (2003: 15-16).

\section{Latar Belakang}

Pemilihan latar belakang dapat juga dipengaruhi oleh budaya-budaya serapan yang berkembang pada era itu. Selain memperkuat citra dari subjek, latar belakang mampu menciptakan kesan keseluruhan.

\section{Fungsi}

Soedjono memaparkan aspek formal dalam fungsi fotografi potret yang mana dalam keseharian seringkali dijadikan bahan identitas pada kartu penduduk atau disebut dengan KTP, SIM atau surat ijin mengemudi, kartu pelajar, ijazah, buku pernikahan, dan beberapa bentuk penunjuk identitas pribadi lainnya. Namun apabila melihat dari sisi politik, foto potret seringkali dijadikan acuan sebagai bentuk kampanye seseorang yang menjadi wakil dari lembaga tertentu. Dengan penggunaan foto potret sebagai media kampanye akan mampu menarik simpati publik untuk menyuarakan aspirasi dan pilihannya, (2006: 118-119).

\section{Teknis}

Teknik pengambilan gambar pada fotografi potret terkesan sederhana, namun sangat berpengaruh pada karakter yang ditampilkan. Ketika gambar diambil dengan cara menyeluruh atau dikenal dengan teknik Long Shot, akan ada beberapa makna yang dapat ditafsirkan dari mulai posisi kaki, jenis pakaian yang dikenakan, hingga ukuran postur badan sesorang. Ada juga yang disebut dengan Medium Shot, yaitu pengambilan gambar secara sebagian atau dalam seni rupa murni seringkali disebut dengan Torso, yaitu pengambilan hanya dari kepala hingga pinggang. Teknik 


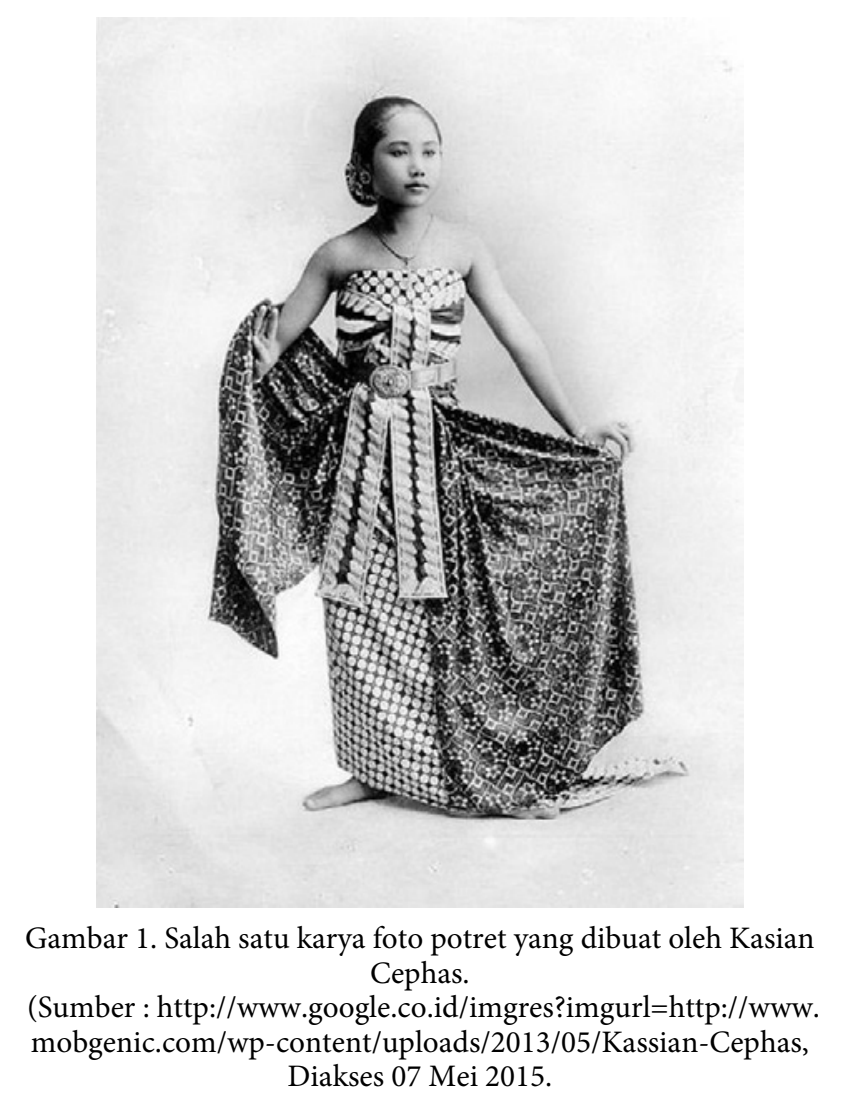

Close-Up ialah pengambilan gambar yang khusus memperlihatkan wajah. Sedangkan dengan Medium Close-Up hanya menampilkan kepala sampai bahu dari si objek (Irwandi \& M. Fajar Apriyanto, 2012: 11).

Untuk mengupas hal-hal yang berkaitan dengan fotografi potret, penulis menggunakan buku yang ditulis oleh Irwandi dan M. Fajar Apriyanto dengan judul Membaca Fotografi Potret : Teori, Wacana, dan Praktik yang diterbitkan oleh Gama Media Yogyakarta pada tahun 2012. Berbagai pendekatan dikupas secara lugas dalam buku ini, menjadikan acuan yang baik dalam proses pembacaan fotografi potret. Selain pembahasan tentang fotografi potret, penulis juga menjadikan poin representasi dan interpretasi terhadap fotografi yang ditulis Tubagus P. Svarajati dalam buku Photagogos yang diterbitkan oleh penerbit Suka Buku di Semarang pada tahun 2013.

\section{Fotografi dalam Seni Stensil}

Stensil merupakan teknik penerapan gambar atau tulisan hasil perekaman. Stensil biasanya menggunakan kertas karton sebagai pencetak lalu pada bagian-bagian tertentu dilubangi untuk akhirnya menjadi area disemprotkannya cat aerosol dan membentuk siluet pada objek. Stensil juga termasuk kedalam seni cetak yang keberadaanya sudah sangat lama, sekitar 22.000 tahun lalu, dan dapat dikatakan sebagai simple idea proved very adaptable troughout history and across the globe, dikatakan Manco dalam Stencil Graffiti (2002: 7).

"Stencils, much like signature graffiti writing, require few resources for production: a relatively firm surface, a utility knife and spray-paint. Stencil artists most often utilize cardboard. Acetate, metal, wood or plastic laminate to create a durable surfacefor their designs. One cut, the stencil can be used repeatedly and in that way operates like a tag", dikatakan Anna Waclawek (2011: 35-36).

Seni jalanan adalah mengacu pada bentuk ekspresi seni yang ditemukan di ruang publik, dan dengan demikian secara terbuka diakses oleh semua orang. Di dalamnya juga terdapat seni tempel, stensil, kolase, seni tape, cuts-out dan urban knitting (Jakob, 2014: 9). Seni jalanan atau biasa disebut street art kemudian muncul menjadi istilah yang dipakai untuk membedakan dengan karya seni yang dibuat dan ditempatkan di jalanan dengan meminta ijin kepada pihak yang berwenang. Seni jalanan merupakan perkembangan dari grafiti yang biasanya dibuat dengan cat semprot (aerosol). Penempatannya dilakukan tanpa ijin dari pihak berwenang dan dilakukan dengan sengaja (misalnya: gerbong kereta, pos polisi, papan reklame, dan lain-lain) terkadang memicu timbulnya perkara yang sering menyebabkan pelaku seni jalanan dianggap sebagai vandalism, Barry (2008: 30). 


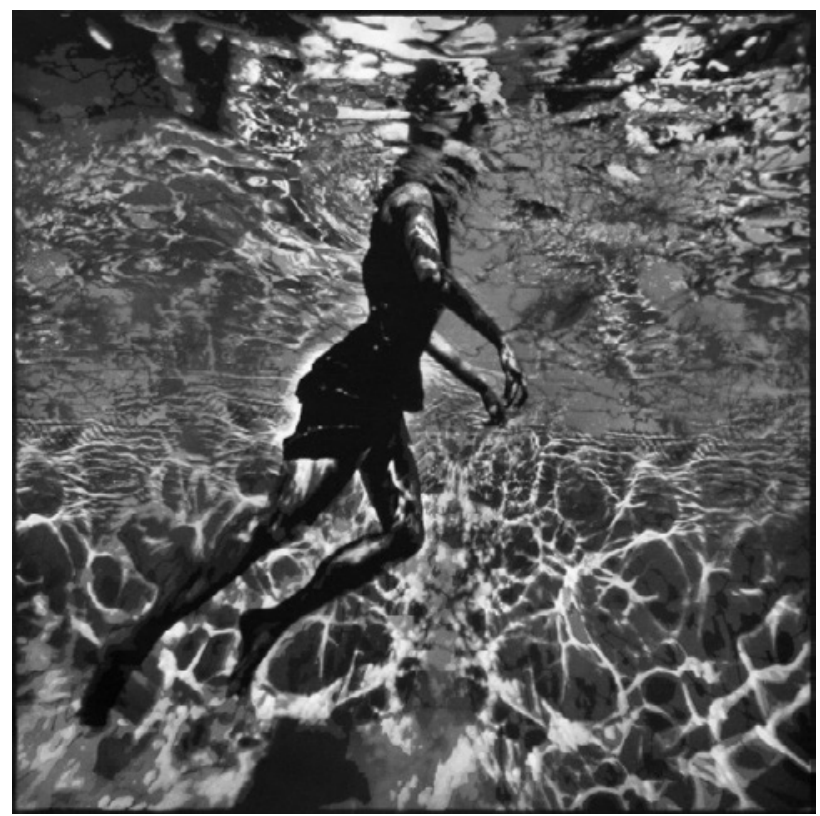

Gambar 2. Salah satu karya stensil Logan Hicks dari hasil foto underwater yang dibuatnya.

(Sumber :http://www.google.co.id/imgres?imgurl=http:// dailydujour.com/wp-content/uploads/2013/03/001-48X48-itsthe-waiting-that-kills-you, Diakses 3 Mei 2015)

Seni stensil dan fotografi sebenarnya sudah sangat dekat. Hal tersebut ditandai oleh proses yang dilakukan oleh seorang seniman urban bernama Logan Hicks. Hicks mengolah fotografi dengan terapan pada seni stensil. Aplikasi dilakukan dengan mengikuti jatuhnya bayangan dan memanipulasi gelapterang pada fotografi dengan menggunakan lapisan-lapisan (layers) pada kertas yang telah dilubangi sesuai dengan bagian bayangan pada foto. Hicks mengejar efek realis yang dikombinasi dengan efek poster yang tidak asing dalam fotografi, atau sering disebut dengan posterize effect.

Seniman stensil lain yang juga menggunakan fotografi sebagai acuan terhadap pembentuk visual karyanya yaitu Blek Le Rat dan Banksy. Blek Le Rat merupakan pelopor parodi dalam bentuk stensil yang akhirnya diadaptasi oleh Banksy. Karyakarya mereka memuat isu politik dan situasisituasi populer yang ditemuinya. Fotografi ditransformasikan oleh keduanya dengan lebih sederhana. Bentukan citra visual yang mudah diingat oleh audiens berhadapan langsung dengan karyanya di ruang-ruang publik. Blek Le Rat dan Banksy mampu mengagetkan audiens yang menjumpai karya-karya mereka dikarenakan detail yang diperlihatkannya saat mengubah bentuk fotografi menjadi seni grafis namun tidak menghilangkan kesan realisnya, meskipun efek posterize dari fotografi diadaptasi untuk memberi kesan lebih sederhana.

\section{Stensil dalam Seni Jalanan}

Tesis dengan judul Seni Jalanan Yogyakarta yang dibuat oleh Syamsul Barry untuk memenuhi syarat gelar Magister Humaniora, Program Magister Ilmu Religi dan Budaya (cultural studies) Universitas Sanata Dharma Yogyakarta yang berisi pengamatan Syamsul terhadap kecenderungan karya seni diwujudkan dalam sebuah aksi jalanan. Tesis ini mengupas seni jalanan dari awal tahun 2000, baik secara aksi maupun pengaruhnya. Namun Syamsul Barry tidak mengupas seni stensil lebih dalam, karena penelitian yang dilakukannya terfokus pada seni rupa jalanan secara umum.

Dalam buku berjudul Hip-Hop : Perlawanan dari Ghetto (Bambaata, 2005: 90-91) yang diterbitkan Penerbit Alinea Yogyakarta pada tahun 2005, menjelaskan tentang sub-kultur Hip-Hop yang berhubungan erat terhadap perilaku para pelaku seni jalanan. Beberapa istilah yang berhubungan dengan pengkajian fotografi ini khususnya istilah-istilah propaganda yang dilakukan para pelaku seni stensil dijelaskan dalam tulisannya, seperti tagging yang berarti tanda atau menandai lokasi dengan identitas, chillin yang berarti turun ke jalan untuk menggambar, bombing yang berarti melakukan teror identitas di sudut-sudut publik yang biasanya menimpa karya street art lain. Kai Jakob yang menulis buku Street Art in Berlin terbitan Jaron Verlag Berlin di tahun 2014 ini membahas perkembangan seni jalanan secara luas, meskipun secara garis 
besar mengarah pada budaya seni jalanan di Berlin, dikarenakan seni jalanan sudah seperti bagian kehidupan masyarakat Berlin. Kurangnya referensi pustaka yang membahas tentang pergerakan seni jalanan dalam negeri menjadikan buku ini sebagai acuan penulis untuk meraba aksi seni jalanan sebagai pijakan mengkaji karya-karya Digie Sigit.

Buku dari Tristan Manco dengan judul Stencil Graffiti yang diterbitkan Thames \& Hudson di United Kingdom pada tahun 2002 ini membahas grafiti dan stensil dari mulai teknik hingga gabungan di antaranya, juga pengaruh fotografi dalam proses pembentukannya. Manco mengatakan bahwa para pelaku stensil memiliki tempat dalam pikiran untuk kedua alasan estetika dan untuk penonton. Selain Manco, pembahasan tentang seni jalanan hingga propagandanya, bahkan pembahasan stensil dari era Blek Le Rat hingga Banksy dipaparkan lugas dalam Graffiti and Street Art (World of Art) yang diterbitkan di New York pada tahun 2011 oleh penerbit Thames $\&$ Hudson. Wacklawek memaparkan bahwa stensil termasuk sebuah teknik yang paling mudah diaplikasikan di jalanan. Selain secara teknik pengaplikasiannya yang mudah, kertas cetakan pun mampu diaplikasikan berkalikali, di berbagai tempat berbeda. Dengan menggunakan stensil, para seniman seni jalanan menghidupkan ide-ide yang menantang audiens, dan mereka lakukan secara terbuka.

Meskipun stensil adalah tidak kekal, dan banyak yang tidak tetap untuk waktu yang lama, melalui penempatan publik mereka dapat mencapai atensi publik lebih luas dan sangat mungkin menyebabkan beberapa orang mulai berpikir secara berbeda. Tidak jarang juga hal tersebut menjadi peluang timbulnya berbagai pertanyaan, dan pemilihan lokasi distribusi dari stensil juga sangat penting seperti dikatakan Saydak dalam tesisnya ( 2011: 26).
Pengaplikasian dari teknik stensil diartikan lebih efisien dibandingkan dari beberapa teknik street art lain misalnya wheat paste, yaitu teknik menempel gambar yang sudah dicetak pada media kertas, bentuk tampilannya hampir menyerupai poster. Kemudian kertas-kertas tersebut didistribusikan di ruang publik dengan cara menempelkannya pada media tertentu seperti tembok-tembok bangunan lalu diratakan menggunakan rol cat. Pada dasarnya, seni stensil yang erat hubungannya dengan tanggapan-tanggapan mengenai isu-isu politik dan kota menjadikan seni stensil semacam komentar langsung akan keadaan yang terjadi, keadaan tersebut kuat akan kritikan-kritikan sosial yang dikemas menjadi suguhan seni visual yang mudah diaplikasikan di ruang publik.

Digie Sigit meluncurkan buku biografi singkatnya dengan judul Tes.Ti.Mo.Ni. yang diterbitkan penerbit Graphic Victim Yogyakarta pada tahun 2013 yang merupakan kumpulan proses kreatif Digie Sigit dalam menggabungkan teknik fotografi yang akhirnya dikemas menjadi karya stensil. Selain itu, di dalamnya berisi konsep besar dari pamerannya yang berjudul sama dengan buku tersebut. Konsep yang diusung dalam pamerannya tersebut ialah pesan terhadap lingkungan sekitar yang berhubungan langsung dengan generasi yang akan datang.

\section{Semiotika}

Istilah semiotika secara etimologis berasal dari kata Yunani semeion yang berarti "tanda". Tanda itu sendiri didefinisikan sebagai sesuatu yang atas dasar konvensi sosial yang terbentuk sebelumnya, dapat dianggap mewakili sesuatu yang lain (Sobur, 2000: 16). Pengertian "tanda" pada masa itu masih bermakna sesuatu hal yang menunjuk pada adanya hal lain. Manusia hampir tidak akan ada tanpa simbol-simbol (Maclver dalam Dillistone, 2002: 15). 
"Signs take the form of words, images, sounds, odours, flavours, acts or objects, but such things have no intrinsic meaning and become signs only when we invest them with meaning. 'Nothing is a sign unless it is interpreted as a sign", Peirce (1931-58).

"Tanda berbentuk kata-kata, gambar, suara, bau, rasa, tindakan atau benda, tetapi hal-hal tersebut tidak memiliki makna intrinsik dan menjadi tanda-tanda hanya tanpa memaknainya atau jika tidak dimaknai. "Tidak ada tanda kecuali ditafsirkan sebagai tanda", dikatakan oleh Peirce (1931-58).

Sebuah tanda representamen (representamen), menurut Charles S. Peirce adalah sesuatu yang bagi seseorang mewakili sesuatu yang lain dalam beberapa hal atau kapasitas. Sesuatu yang lain itu dinamakan sebagai interpretan (interpretant) dari tanda yang pertama pada gilirannya mengacu pada objek (Budiman, 2003:25). Charles Morris mengklasifikasikan perhatian atas ilmu tentang tanda-tanda ke dalam tiga cabang penyelidikan (branches of inquiry), yaitu sintaktik, semantik, dan pragmatik.

Analisis semiotika modern dapat dikatakan dipelopori oleh dua orang. Pertama, Ferdinand de Saussure, ahli linguistik dari Swiss (1857-1913), yang mengemukakan pandangan bahwa linguistik hendaknya menjadi suatu bagian ilmu pengetahuan umum tentang semiologi. Kedua, Charles Sanders Peirce, filsuf Amerika (1839-1914). Peirce menyebut sistemnya sebagai semiotika, dan telah menjadi istilah dominan yang digunakan untuk ilmu tentang tanda-tanda. Teori dari Peirce menjadi grand theory dalam semiotik. Gagasannya bersifat menyeluruh, deskripsi struktural dari semua sistem penandaan (Sobur, 2002:96-97). Adapula tanggapan semiotika di antara keduanya yaitu Charles S. Peirce, mendefinisikan semiotika tidak lain daripada sebuah nama lain bagi logika yakni doktrin formal tentang tanda-tanda (the formal doctrin of sign). Ferdinand de Saussure, memberi pengertian lain bahwa semiotika atau semiologi sebagai bidang kajian ilmu umum tentang tanda-tanda di dalam masyarakat. Dengan demikian maka Pierce lebih menganggap bahwa semiotika sebagai cabang dari ilmu filsafat sedangkan Sassuare ahli merumuskan semiotika sebagai kajian psikologi sosial (Budiman, 2003 : 3).

\section{Ikon, Indeks dan Simbol dalam Semiotika}

Seperti dalam pembahasan sebelumnya tentang tanda, bahwa semiotika tidak boleh melupakan dua tokoh pencetus teori-teori semiotika kontemporer yaitu Ferdidand de Saussure dan Charles S. Peirce. Saussure yang pernah mengikuti kuliah sains di University of Geneva sebelum akhirnya masuk dalam studi bahasa. Saussure seringkali menggambarkan tanda sebagai unsur biner yaitu struktur yang terdiri dari dua bagian: (1) bagian fisik atau disebut dengan penanda, dan (2) bagian konseptual yang mana seringkali disebut dengan petanda. Sedangkan Peirce yang pernah menjalani pendidikan di Harvard University dan dipenuhi suasana ilmu filsafat dalam hidupnya dikenal dengan teori pragmatisme. Apabila membahas tanda dalam pemikiran Pierce maka tanda disebut sebagai representamen dan konsep, benda, gagasan, dan seterusnya hingga menuju pada objek (Danesi, 2010: 37).

Definisi Peirce terhadap tanda akhirnya dipadatkan pada tiga istilah populer dari teori Peirce yaitu ikon, indeks, dan simbol. Ikon bagi Peirce adalah tanda yang mewakili sumber 
acuan, acuan tersebut melalui bentuk replikasi, simulasi, imitasi dan persamaan. Sedangkan pada poin ikon, Peirce mengemukakan bahwa ikonisitas dapat ditemukan pada wilayah representasi nonverbal. Pada dasarnya ikonisitas membuktikan bahwa persepsi manusia sangat tinggi terhadap pola-pola berulang dalam warna, bentuk, dimensi, gerakan, bunyi, rasa, dan seterusnya. Indeks kemudian memberikan pemahaman bahwa indeksikalitas membuktikan bahwa kesadaran manusia bukan hanya memerhatikan pola warna, bentuk, dan lain-lain dan menghasilkan tanda ikonis, tapi juga memerhatikan halhal berulang dalam hubungan antara sebabakibat yang tidak pasti dalam waktu dan ruang (Danesi, 2010: 43).

Simbol dalam pamahaman Peirce yaitu mewakili acuannya dalam cara yang lebih konvensional. Bagi Pierce, kata-kata berarti juga simbol. Tapi selain itu, penanda manapun dari sebuah objek, baik suara, visual, gerak, tetap dapat bersifat simbolik.

"Orang di seluruh dunia menyepakati simbol-simbol tertentu sebagai sistem kilat untuk mencatat dan memanggil kembali informasi."

(Danesi, 2010: 47).

Dalam kerangka Barthes, konotasi identik dengan operasi ideologi, yang disebutnya sebagai 'mitos' dan berfungsi untuk mengungkapkan dan memberikan pembenaran bagi nilai-nilai dominan yang berlaku dalam suatu periode tertentu.

Secara sepintas, dapat dicatat bahwa formulasi ini menggarisbawahi poin bahwa 'apa yang signifier atau signified sepenuhnya tergantung pada tingkat di mana analisis beroperasi: seuatu yang ditandai pada satu tingkat dapat menjadi penanda pada tingkat lain' (Willemen, 1994: 105 ). Hal tersebut adalah mekanisme yang mungkin tampak tandatanda untuk menandakan satu hal tetapi sarat dengan beberapa makna. Mengubah bentuk penanda sekaligus mempertahankan signified yang sama bisa menghasilkan konotasi yang berbeda. Fiske menempatkan denotasi adalah apa yang difoto, konotasi adalah bagaimana hal itu difoto (Fiske 1982, 91).

"However, in photography, denotation is foregrounded at the expense of connotation. The photographic signifier seems to be virtually identical with its signified, and the photograph appears to be a 'natural sign' produced without the intervention of a code". (Hall, 1980: 132).

"Namun, dalam fotografi, denotasi adalah dikedepankan dengan mengorbankan konotasi. Penanda fotografi tampaknya hampir identik dengan signified, serta foto itu tampaknya menjadi 'tanda alam' diproduksi tanpa intervensi dari kode". (Hall, 1980: 132).

\section{Denotasi dan Konotasi}

Dalam semiotika hasil pemikiran Barthes akan denotasi, sebenarnya denotasi dapat diartikan sederhana sebagai 'makna kamu', yang berarti penerjemahan visualnya sesuai dengan apa yang dihadirkan langsung.

Konotasi dalam semiotika seringkali memiliki muatan perasaan dan nilai tertentu yang akhirnya tidak dapat sama satu dengan lainnya. Konotasi mampu menghasilkan makna yang beragam, dikarenakan konotasi tak jarang sangat subjektif. Makna konotasi harus dipelajari dan dikuasai berdasarkan pengalaman keberbahasaan dan pemakaiannya (Parera, 2004: 98).

Pada karya-karya Digie Sigit, semiotika dapat diposisikan pada hasil akhirnya. Karena statement berkeseniannya sebagai seorang seniman seni jalanan yang berhubungan dengan propaganda publik, jelas memicu anggapan audiens secara langsung maupun 
tidak terhadap karya seni stensilnya maka penggunaan tanda-tanda dalam karyanya yang mengandung makna-makna tertentu jelas akan lebih mampu merepresentasikan gagasan yang dibuatnya. Penggunaan foto potret sebagai perekam realitas pun mempermudah audiens mencerna visual dan pesan yang ingin dikemukakan.

\section{Estetika}

Istilah estetika melalui beberapa uraian yang berkembang menjadi ilmu tentang keindahan. Terdapat beberapa unsur estetika yang ada yaitu : (a) wujud, (b) bobot, dan (c) penampilan.

Pemahaman secara umum tentang nilai estetika pada suatu karya seni ini adalah setiap pancaran nilai-nilai keindahan yang tercermin dari sosok karya seni yang memberikan kualitas dan karakter tertentu (Soedjono, 2007: 3). Dalam fotografi, estetika dibagi menjadi dua wilayah, yaitu estetika pada tataran ideasional, dan estetika teknikal, seperti yang dipaparkan Soedjono (2006: 1-21). Tataran ideasional dalam fotografi menyangkut keinginan untuk menunjukan jati diri dan ide pribadi seorang fotografer yang tercermin dalam konsep dan pendekatan estetis yang dipilihnya (Irwandi \& M. Fajar Apriyanto, 2012: 13). Dalam karya-karya seni stensil Digie Sigit yang banyak melakukan ekspos terhadap figur menggunakan foto potret terlihat bahwa objek yang difotonya seringkali mengekspresikan sesuatu dengan mimik wajah atau gestur yang khas.

Pada seri Tirolesia, Sigit banyak mengambil momen secara diam-diam (candid) untuk menampilkan ekpresi yang natural. Foto potret merupakan media pengabadian identitas yang sifatnya sementara karena identitas selalu berubah seiring dengan berjalannya waktu. Identitas tersebut akan tampak pada fotografi potret yang sering berkaitan dengan karakter, personalitas, posisi sosial, relasi- relasi, profesi, umur, dan gender seseorang yang dijadikan subjek dalam karyanya.

Pada sisi pendekatan estetika fotografi, penulis mengacu pada buku dari Soeprapto Soedjono dengan judul Pot-Pourri Fotografi pada tahun 2007. Soedjono dalam bukunya menyatakan tentang estetika dalam fotografi yang dibagi menjadi dua aspek, teknikal dan aspek ideasiaonal. Aspek ideasional berhubungan dengan ide dan gagasan pencipta yang akan melandasi karyanya. Dalam aspek ideasional, seniman atau kreator memasukan berbagai pemikiran hingga identitas yang akan memperkuat gagasan dan kandungan karya seninya. Selain aspek ideasional, dalam estetika fotografi juga terdapat aspek teknikal. Soedjono (2006 : 14-18) Dalam aspek teknikal, beberapa efek dapat dihasilkan dengan menggunakan teknik-teknik tertentu yang juga akan berpengaruh pada hasil akhirnya, seperti dalam seni stensil yang sangat membutuhkan siluet, jika menggunakan pendekatan teknikal pada estetika fotografi, hal tersebut dapat dicapai menggunakan teknik pencahayaan khusus untuk mengejar kesan tersebut pada saat proses pembuatan foto potret sebelum akhirnya ditransformasi menjadi seni grafis. Markowski menyatakan (1984: 70-140) tentang sepuluh elemen dasar pembentuk imaji dalam fotografi yaitu cahaya; nada (tone); bayangan; bentuk; garis; tekstur; ukuran; perspektif; ruang; dan komposisi. Dari sepuluh elemen visual yang dikatakan Markowski, dalam penelitian ini hanya akan dipakai empat elemen dalam mengkaji foto potret yang dibuat oleh Digie Sigit dalam proses pembentukan seni stensilnya, diantaranya cahaya, bayangan, bentuk dan ruang.

Dalam fotografi, cahaya digunakan untuk memunculkan tekstur, bentuk, volume, relasi spasial, dan aspek pewarnaan. Sedangkan pada bagian bayangan, Markowski meyakinkan bahwa vitalitas cahaya akan berpengaruh terhadap kemampuan untuk 
membangun kesan dramatis pada imaji yang diciptakan (Irwandi \& M. Fajar Apriyanto, 2012: 22). Pada karya stensil kesan yang ditampilkan dari hasil pencahayaan dan timbulnya bayangan terhadap objek menjadi faktor utama yang sangat berpengaruh pada kesan nyata yang akan ditampilkan. Hal tersebut berhubungan dengan sifat dan karakteristik seni stensil yang sangat bertumpu pada bentuk yang diciptakan oleh bayangan.

\section{Foto Potret dalam Karya Digie Sigit}

Kecanggihan fotografi yang mampu mengantarkan visual kenyataan dimanfaatkan Digie Sigit dalam 'merekam' gagasannya dalam pose model baik dengan sebuah perintah maupun direkamnya secara diam-diam atau candid. Sifat foto potret yang sangat ampuh sebagai media mendeteksi identitas bahkan hal-hal yang berhubungan dengan strata sosial hingga sejarah yang terjadi, memang tidak serta-merta keseluruhannya menjadi landasan bagi Digie Sigit dalam memerlakukan foto potret. Digie Sigit menjadikan gagasan pemikirannya untuk kemudian diwujudkan pada tampilan objek yang dengan pose tertentu sebagai rangkuman penggambaran gagasannya tersebut.

Dalam seri-seri yang dibuatnya, khususnya DS12 dan DS13 yang banyak menggunakan figur Reyna sebagai objek karyanya, Digie Sigit menokohkan anak kecil perempuan sebagai metode pengingat dan pengantar pesan dari hasil pemikirannya akan berbagai hal. Reyna seringkali direkam dalam potret dengan pose alami yang tidak menghilangkan karakter 'anak-anaknya'.

Pemahaman Bate (2009: 73) mengenai empat elemen potret, yaitu wajah, pose, pakaian, dan lokasi sebenarnya tampak cukup jelas dihadirkan dalam foto-foto potret yang dibuat oleh Digie Sigit, meskipun akhirnya saat terjadi pengolahan menjadi karya grafis (stensil), beberapa elemen tersebut ada yang dihilangkan, seperti lokasi, dikarenakan sifat stensil yang dibuat oleh Digie Sigit adalah murni sebuah penyampai pesan-pesan yang seringkali bernada provokatif.

Tidak dapat dipungkiri bahwa fotografi juga mampu menjadi pembentuk maknamakna terhadap susunan simbol bahkan tanda yang terekam. Karya-karya potret yang dibuat oleh Digie Sigit apabila ditarik pada pemahaman aspek estetika fotografi dalam poin aspek teknikal memang tidak mengandung rangkaian teknik yang rumit dalam proses pembuatan potretnya, Digie Sigit seringkali mengabadikan sitter dalam perilaku mendokumentasi sebuah gestur yang dikemas sebagai 'penyampai pesan' secara visual, dalam hal ini memanfaatkan potret. Seringkali Digie Sigit hanya meminta Reyna sebagai sitter-nya untuk bergaya natural, tanpa arahan. Digie Sigit hanya menceritakan pada Reyna mengenai maksud dari potret tersebut. Usia Reyna yang masih dikategorikan anak-anak memang menjadi keunikan tersendiri apabila melihat proses kolaborasi yang dikerjakan Digie Sigit bersamanya.

\section{Sekilas Tentang Stensil Digie Sigit}

Digie Sigit atau yang dikenal dengan inisial DS memulai melakukan tagging (tanda yang dipakai para seniman jalanan, baisanya bisa berupa inisial nama, logo, atau visual tertentu) stensil di ruang publik pada tahun 2003 dengan visual tank baja yang ditaruh pada sebuah kotak pendingin ruangan yang ditemukannya di sekitar kompleks Taman Budaya Yogyakarta. Pada awal Sigit membuat stensilnya, Sigit belum menaruh inisial DS yang merupakan singkatan dari namanya. Awal Sigit menaruh inisial DS pada karya-karya stensilnya ialah dimulai pada tahun 2010, yaitu dengan inisial DS10. 
"Memasuki ruang kemungkinan untuk mendapatkan konsentrasi langsung dari publik yaitu dengan mencetak langsung karyaku pada benda-benda yang kutemukan di ruang publik. Aku memilih menggunakan metode ini dikarenakan untuk meminimalisir eksklusifitas seni. Konteks berbagi, yaitu ya membagi pada publik, ya langsung mencetakakan di jalan." (Digie Sigit, wawancara langsung pada tanggal 26 Mei 2015, pukul 18: 17 WIB)

\section{Fotografi Sebagai Pembentuk Visual Stensil}

Sejak ditemukannya, fotografi menjadi sebuah media perekam yang paling ampuh menghadirkan imaji sesuai dengan realitanya. Setelah fotografi ditemukan, berbagai bentuk seni visual banyak yang memanfaatkan keunggulan media fotografi. Dalam media periklanan, hampir seluruh visual (selain teks) berasal dari proses fotografi. Keuntungan menggunakan media fotografi yang ditujukan bagi publik ialah objek yang terekam sangat mempermudah audiens mencerna dan cara menghadirkan kenyataan lebih dapat terasa. Dalam seni stensil, peranan fotografi sangat penting dikarenakan stensil membutuhkan transfer objek (imaji) visual yang memiliki unsur gelap-terang. Media fotografi sangat mampu menghadirkan unsur dan karakteristik gelap-terang objek sangat realis. Seni stensil dapat terwujud apabila objek yang dibuat memiliki muatan dimensi cahaya, dapat diartikan bahwa bagian-bagian bayangan dari objek hadir dengan kuat. Hal tersebut dikarenakan dalam karya seni stensil hanya salah satu bagian saja yang dapat ditampilkan dalam pembentukan citra visual, contohnya apabila ingin menunjukan bentuk tertentu, bagian gelap dari objek tersebut yang dilubangi dan akhirnya menjadi area disemprotkannya cat aerosol.
Sedari awal berkembangnya, stensil merupakan terusan dari bidang seni grafis yang mana keseluruhan tekniknya adalah mencetak. Namun perbedaan seni stensil dengan seni grafis lainnya terletak pada teknik mencetak yang dimaksud. Teknik mencetak dalam seni stensil tertumpu pada kertas mal sebagai pencetak gambar, apabila kertas yang telah dilubangi tersebut hancur, maka yang aktifitas cetaknya terhenti. Seni stensil hanya dapat diaplikasikan pada bidang datar, dan sangat tergantung pada kertas pencetak yang telah dilubangi.

Pada penjelasan sebelumnya telah dijelaskan bagaimana strukturalisme semiotik mengkaji simbol atau tanda dari suatu karya visual. Bagaimana sebuah karya visual mampu mengkomunikasikan tanda dengan melalui pemahaman ikon, indeks dan simbol, dan bagaimana signifier dan signified bekerja di dalamnya, dan diteruskan dengan makna denotasi juga konotasi pada karya. Pada pembahasan berikut, stensil mengacu pada fotografi, maka penulis juga akan memaparkan bagaimana karya stensil melakukan signifikasi yang dipengaruhi oleh kode fotografi, kode fotografis merupakan segala potensi media fotografi yang digunakan untuk menghadirkan sign yang sudah diproduksi pada tatanan kultural yaitu kamera, tata cahaya, komposisi dan editing.

\section{Sosok Reyna dan Makna yang Terkandung}

Digie Sigit memiliki nama alias sebagai penanda identitasnya saat di ruang publik dengan DS yang diikuti angka penunjuk tahun dibuatnya karya tersebut. Pada seri DS, intensitas Sigit mengikutsertakan Reyna (puteri tunggalnya) sebagai kolaborator bukan tanpa alasan. Reyna seringkali berada dan menyaksikan aktifitas Sigit saat mengolah visual-visual yang akhirnya menjadi sebuah karya stensil. Tak jarang Sigit mengajak Reyna 
untuk mendiskusikan berbagai hal sebagai metode melatih kepekaan Reyna yang masih duduk di bangku sekolah dasar. Salah satu karya Sigit dalam DS12 yang dibuat bersama dengan Reyna adalah figur Reyna dengan baju tidurnya memegang kertas bertuliskan "Hentikan Perang!" tersebut merupakan hasil diskusi Sigit dengan Reyna tentang banyaknya korban perang yang masih anak-anak dan dibiarkan begitu saja. Dalam gambar 4 terlihat bahwa Reyna memakai baju tidur dan kacamata. Baju tidur seringkali dikonotasikan sebagai kealamian, natural, santai, hingga lugu dana apa adanya.

Karakter Reyna (lihat gambar 4) terlihat dalam karya Sigit memiliki peran sebagai identitas dari gagasan besar berangkatnya konsep dan isu-isu yang diungkapkannya. Sigit sangat peduli tentang generasi setelahnya yang diwakili oleh figur Reyna sebagai putrinya sebagai pewaris segala hal yang dilakukannya sekarang. Dalam arti sederhana adalah "apa yang dilakukan kini, hasilnya akan terasa esok". Gagasan tersebut menjadi pijakan Sigit dalam mengolah berbagai kasus disekitarnya. Seperti dalam karya berjudul "Hentikan Perang!", Sigit memvisualkan pesan tersebut hanya melalui figur seorang anak sebagai metode menyoal kasus kekerasan terhadap anak yang juga banyak terjadi.

Dalam ilmu semiotika, tanda merupakan segala sesuatu yang berkaitan dengan warna, isyarat, kedipan mata, objek, rumus matematika dan lain-lain sebagainya yang mampu merepresentasikan sesuatu yang lain selain dirinya (Danesi, 2010: 7). Selain berkaitan dengan tanda, semiotika juga mempelajari bagaimana memaknai pesan-pesan yang tersurat dan tersirat melalui susunan simbol-simbol visual. Pada karya-karya Digie Sigit, terutama dalam seri DS12, DS13, dan DS15, Digie
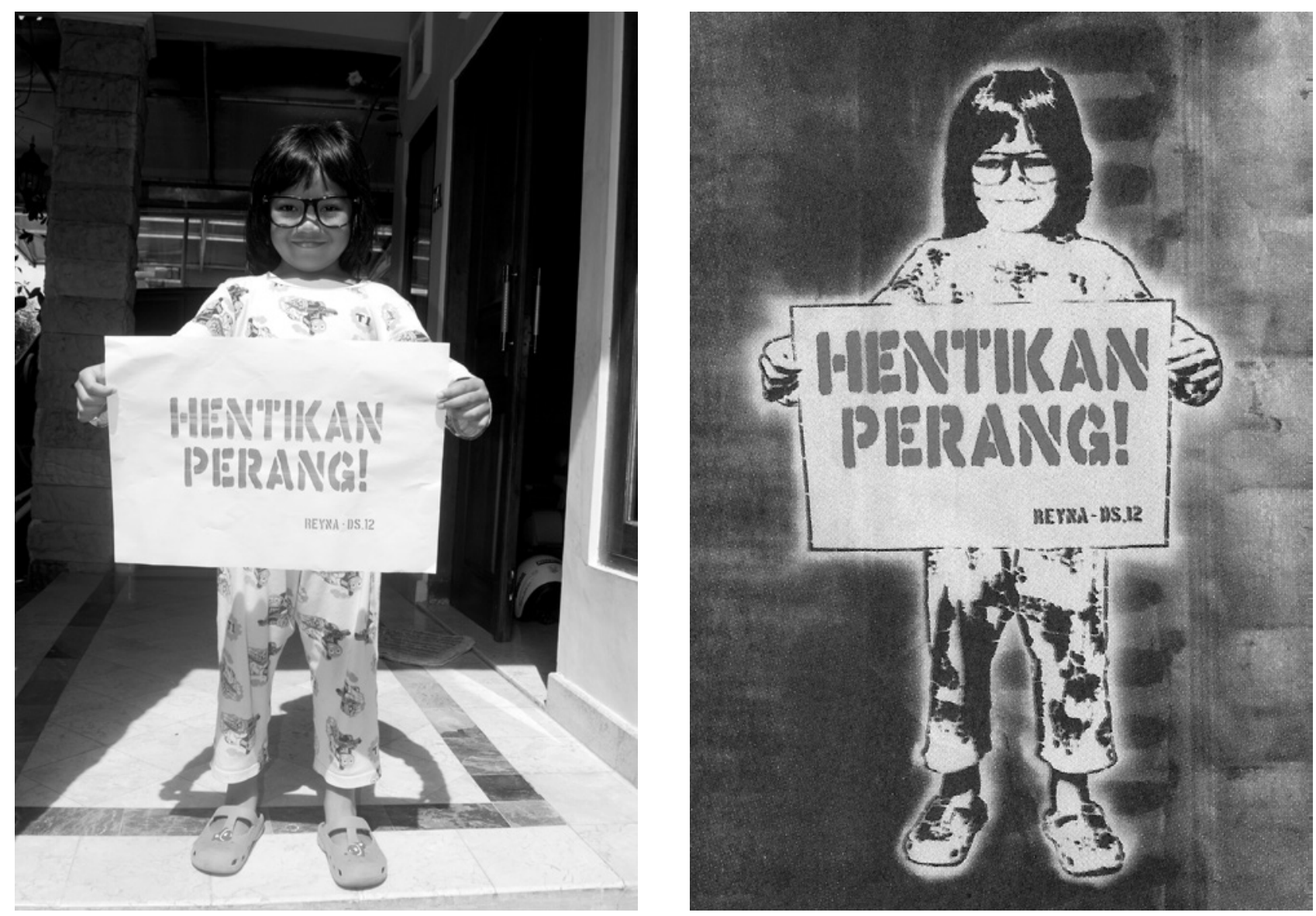

Gambar 4. Foto potret Reyna dalam karya stensil Digie Sigit seri DS12 (kanan) dan hasil foto potret yang telah ditransformasi menjadi stensil (kiri).

Sumber: Dok. Pribadi Digie Sigit, 2012. 
Sigit banyak memainkan gerak tubuh, ekspresi dan pose yang mampu berpotensi melahirkan makna-makna tertentu. Pada pengkajian ini, makna konotasi yang akan menjadi landasan analisis karya-karya yang dibuat oleh Digie Sigit.

Pada proses pemotretan Reyna dalam seri DS12 ini, Sigit menggunakan kamera DSLR (Digital Single Lens Reflect) dengan lensa kit $18-55 \mathrm{~mm}$. Teknik pengambilan gambarnya menggunakan teknik long shot yaitu keseluruhan badan objeknya terekam jelas. Sigit kemudian mengolah hasil foto potret tersebut dengan perangkat lunak olah foto yaitu Photoshop untuk mengatur kontras dan pencahayaan yang dirasakan butuh penyempurnaan dibeberapa sisi. Sigit seringkali meniti-beratkan pengolahan foto pada sisi gelap dan terang yang dihasilkan. Karena dalam membuat stensil, pengolahan objek sangat ditentukan oleh bayangan yang terjadi dari pencahayaannya.

Identitas Reyna terlihat hanya dari beberapa sisi seperti potongan rambut, kacamata, alas kaki, baju yang dipakai, dan ekspresinya. Baju yang dipakai oleh Reyna pun mengalami penyederhanaan, Sigit hanya mengambil kesan umum saja seperti kerah dan lengan panjang, namun motif yang ada pada baju, seperti yang terekam dalam hasil foto sebelumnya memang sengaja tidak ditampilkan.

Secara pencahayaan, Sigit hanya menggunakan cahaya alami tanpa bantuan dari lampu flash. Sigit tidak mengatur kostum Reyna karena baginya ketika Reyna dibiarkan menjadi dirinya dengan wardrobe (pakaian) yang biasa ia pakai akan memberi kesan natural dan tidak menghilangkan kesan bahwa Reyna bukan seorang dewasa. Hal tersebut dilakukan Sigit karena dengan menggunakan figur anak-anak menjadikan metode propaganda yang memuat sindiran akan berbagai hal yang terjadi. Saat berbicara mengenai konteks pemakaian Reyna sebagai media penyampai gagasan dikarenakan seorang anak seringkali dikonotasikan lugu, polos, belum memiliki banyak pengalaman, membutuhkan banyak pengetahuan dan pendidikan, dan ketika gagasan-gagasan Sigit seakan diutarakan oleh seorang anak akan menjadi sebuah sindiran yang kuat dalam karya stensilnya.

\section{Aspek Ideasional dan Makna dalam Seri Tirolesia}

Pendaratan Sigit di sebuah desa kecil di Austria yang bernama Tirol memberikan berbagai kemungkinan dalam mengamati hal-hal baru yang berpotensi untuk dijadikan sebuah gagasan dalam karya seni stensilnya. Digie Sigit memotret seorang wanita paruh baya bernama Maria (gambar 9) yang ditemuinya di Tirol. Signified (penanda) menerangkan bahwa Maria dengan senyuman dan garisgaris kerutan diwajahnya mengkonotasikan usia yang sudah senja. Baju semacam blouse yang digunakannya bagi Digie Sigit adalah semcam ikon orang-orang usia lanjut yang hidup di pedesaan Tirol. Secara estetik, aspek ideasional pada karya ini terletak pada cerita dibalik proses pemotretan dan pemilihan subjeknya. Sigit terkesan saat menemui Maria yang banyak bercerita tentang keadaan genting yang terjadi semasa perang Nazi di Jerman hingga meluas ke Austria, dan desa Tirol menjadi salah satu tempat persembunyian masyarakat Yahudi yang melarikan diri. Maria menjadi salah seorang saksi atas kejadian tersebut, ia juga ikut andil membantu menyelamatkan sebuah keluarga Yahudi yang mencari perlindungan.

Dari kisah di balik itu, Sigit melihat adanya persamaan kejadian secara psikis dengan apa yang terjadi di Indonesia semasa PKI dahulu. Banyaknya keluarga yang berlindung di daerah lain karena terjadinya ancaman dari 
kelompok-kelompok PKI. Teknik pengambilan gambar sosok Maria ini menggunakan teknik pengambilan gambar medium close up sehingga mampu merekam mimik wajah Maria dan elemen pendukung lain seperti baju yang ia kenakan. Hal tersebut menceritakan keadaan dengan jelas apa yang dimaksud dari makna gambar tersebut, yang menjelaskan makna nonverbal. Dalam pelbagai budaya, tanda dan kode tubuh yang mengatur perilaku nonverbal dihasilkan oleh persepsi atas tubuh sebagai sesuatu yang lebih dari sekadar zat fisik, seperti kedipan mata, isyarat tangan, ekspresi wajah, postur, dan tindakan badaniah lainnya mengomunikasikan sesuatu yang relevan dengan budaya dalam situasi-situasi sosial tertentu (Danesi, 2010: 64).

Jika membandingkan hasil fotografi yang masih berupa foto potret dengan fotografi yang telah diolah menjadi karya seni stensil terlihat bahwa kekuatan garis yang ditampilkan dari lapisan-lapisan multi layer pada mal cetakan stensilnya mampu memperkuat objek. Jatuhnya cahaya pada area wajah Maria saat terlihat (gambar 9) sangat lembut, namun pengolahan menjadi stensil mampu mengeluarkan gurat-gurat wajah senjanya lebih berkarakter. Melihat seni stensil yag didistribusikan di ruang-ruang publik, dengan daya serap visual audiens hanya pada hitungan beberapa detik, kekuatan

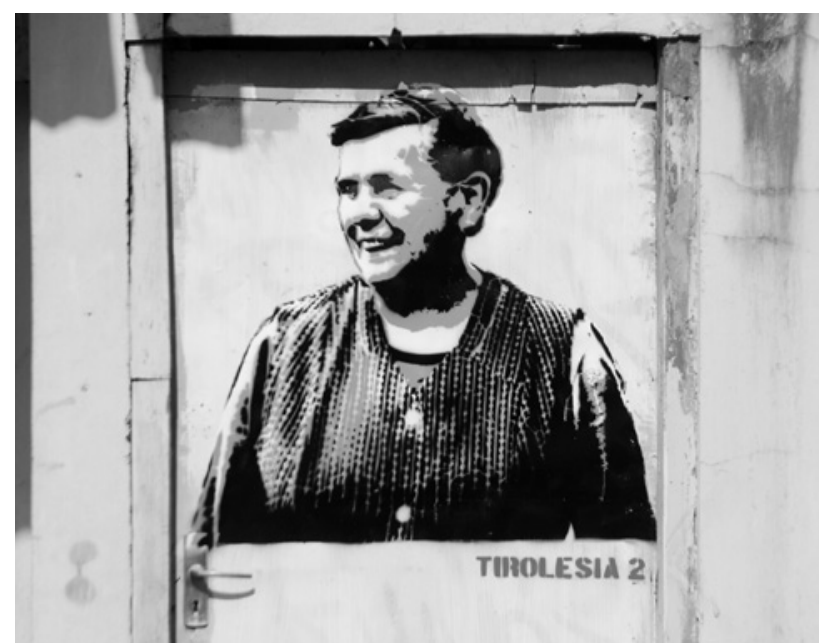

gradasi warna yang ditampilkan karya stensil ini seolah mempermudah audiens menyerap visual tersebut dan mampu menimbulkan potensi menafsirkan masing-masing pencitraan akan simbol-simbol yang terdapat pada karya stensilnya. Mitos-mitos yang bersifat citrawi, dibedakan menjadi dua pesan yang terkandung di dalam sebuah citra, Barthes (1987: 16-27, 33-46).

Lambang atau simbolisasi pada seni visual mengalami perkembangan yang signifikan dan secara langsung maupun tidak langsung dapat menerjemahkan pikiran atau perasaan komunikator pada komunikan. Lambang merupakan sesuatu seperti tanda yang menyatakan suatu hal atau mengandung maksud tertentu. Tanda (sign) dapat membawa imajinasi ke dalam benak manusia, yang kemudian dapat menimbulkan konsep simbol atau ikon. Tanda-tanda visual yang terbentuk dalam Seni stensil Digie Sigit menjadi potensi yang memunculkan kembali realitas yang ditandainya (signified) atau melaksanakan fungsi sebagai penanda (signifier) yang serupa dengan bentuk obyek (terlihat pada gambar).

Fotografi merupakan media visual yang luar biasa. Suatu dunia rekam visual yang dieksplorasi oleh manusia mulai dari pilihan objek, konsep, hingga pengaplikasiannya,

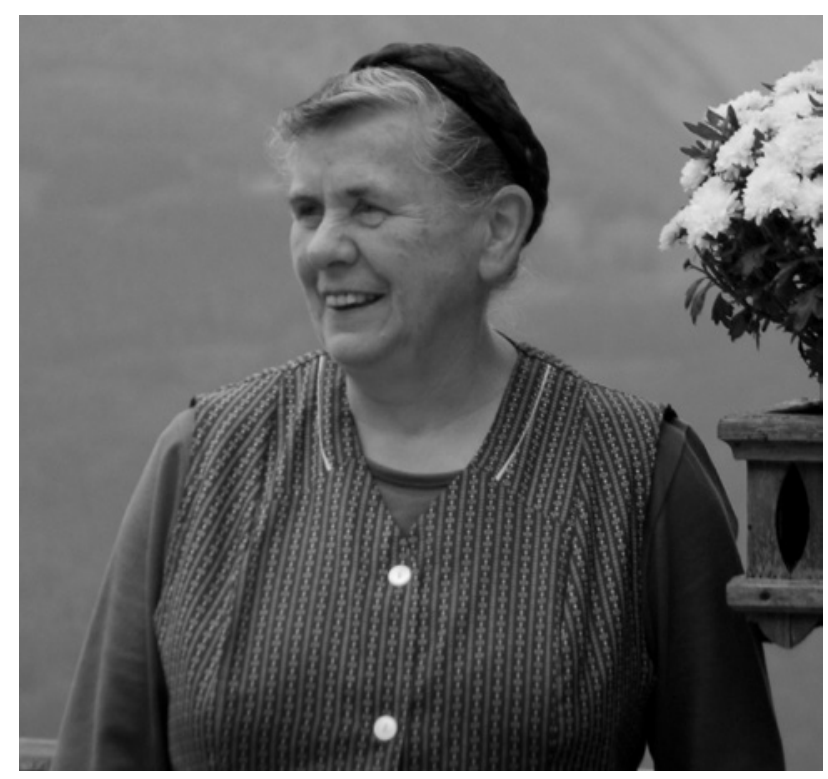

Gambar 9. Foto Potret Maria yang diambil secara diam-diam (kanan) sebagai bahan pembentuk visual karya stensil Digie Sigit pada Seri Tirolesia (kiri). (Sumber: Dok. Pribadi Digie Sigit, 2014) 
baik yang representasional realistis hingga ditambahkan efek visual tertentu seperti dalam hal ini Digie Sigit mengolah foto dengan tambahan efek poster atau dikenal dengan posterize filter. Seni stensil menggunakan kekuatan fotografi untuk memudahkan melakukan identifikasi pembacaan visualnya. Realisme dalam seni stensil diciptakan untuk menangkap keindahan objek-objek nyata yang terekam. Seni stensil memerlukan keunggulan fotografi dalam mencipta dimensi visual dan menghadirkan kenyataan dengan sentuhan estetika seni grafis.

Pesan dan makna yan terkandung dalam karya-karya seni stensil dari Digie Sigit dalam seri DS12, DS13, DS15 hingga Tirolesia terletak pada gagasan Sigit yang tercipta akibat sensibilitasnya memahami dan merasakan segala gejala sosial disekitarnya. hal tersebut seringkali diwujudkan dengan pesan-pesan yang sedikit berbau sindiran yang dikemas ringan dan semacam pengingat dengan menggunakan media visual. Sigit sangat sadar betul tentang pesan moral dari sebuah karya seni, maka dalam prosesnya dia selalu merenungkan berbagai kejadian yang dekat dengannya, hingga metodenya menggunakan Reyna sebagai sitter dalam foto potret yang kemudian ia olah menjadi seni stensil. Kehadiran Reyna yang diibaratkan sebagai figur generasi selanjutnya yang akan mencontoh dan mendapatkan hal-hal yang kita tanam di masa kini telah menjadi identitas kekaryaan dari Digir Sigit. Selain figur Reyna sebagai ikon umum akan sosok anak kecil yang diibaratkan dengan sifat lugu dan polos, namun juga Sigit sadar betul bahwa kehadiran Reyna tidak dapat dihilangkan dari segala intensitas proses berkeseniannya. Berbeda dengan seri Tirolesia, Digie Sigit sama sekali tidak memasukan karakter Reyna, karena seri Tirolesia dibuat sebagai bentuk projek keseniannya selama berada di sebuah desa di negara Austria yang bernama Tirol.
Sehingga muatan figur penanda visualnya lebih banyak orang-orang atau sosok-sosok yang ditemuinya selama berada di Tirol.

Seni stensil dari Digie Sigit ini diteliti dan dianalisis untuk dicari maknanya (pictorial meaning) karena berhubungan dengan gambar atau ikon. Makna muncul dalam penanda (signifier) dan petanda (signified), menjadi konsep mental yang diharapkan muncul dalam kode pesan tertentu. Penggunaan kata kode juga muncul dalam teori semiotik yang dikemukakan oleh Roland Barthes.

\section{SIMPULAN}

Fotografi merupakan media visual yang sangat luar biasa yang mampu mengantarkan realitas dengan sangat mudah. Suatu dunia visual yang dieksplorasi oleh seorang seniman seni jalanan yang mengambil fokus pada seni stensil mulai dari pilihan objek, komposisi objek, hingga makna yang terkandung. Realisme dalam stensil diciptakan untuk menangkap keindahan yang nyata, dan realitas tersebut terwujud akibat adanya proses pengolahan fotografi khususnya foto potret yang dieksplorasi menjadi seni stensil. Fotografi merupakan seni propaganda terbaik dikarenakan perekaman kenyataan yang sangat representasional dan mudah diaplikasikan. Dalam penelitian ini terjadi semacam pandangan terhadap fotografi yang sebenarnya sangat memungkinkan dan berpeluang untuk diwujudkan menjadi seni visual lain.

Posisi fotografi dalam karya seni stensil Digie Sigit sangatlah penting dikarenakan wujud dari seni stensilnya yang merespon kenyataan hanya mampu diwujudkan melalui media fotografi. Dalam hal ini, potret yang dibuat oleh Digie Sigit yang akhirnya diolah menjadi stensilsangat terpengaruh oleh proses fotografi. Foto potret yang memiliki kekuatan menampilkan karakter objek dalam pose dan 
mimik wajah yang kemudian membentuk identitas kuat terhadap objek yang ditampilkan.

Karya seni stensil merupakan karya yang didistribusikan langsung pada ruang publik yang tidak ada negosiasi akan kondisi yang terjadi pada ruang-ruang publik tersebut. Perlakuan seniman jalanan akan ruang pubik yang tidak dapat diprediksi secara langsung terdapat pada proses Digie Sigit dalam mengolah visual, sehingga visual yang dihadirkan harus mampu diterima atau dicerna publik secara mudah.

Pada pembahasan yang telah dilakukan, analisis serta interprestasi pada karya-karya seni stensil dari Digie Sigit dalam seri DS12, DS13, DS15 dan Tirolesia dengan mengambil 5 foto pada keseluruhan serinya, maka selanjutnya penulis menarik kesimpulan dari pembahasan yang telah dilakukan sebelumnya. Pesan-pesan yang disampaikan melalui karya yang yang dibangun oleh Digie Sigit sangat kental dengan sifat-sifat sensitif dan perhatian akan keadaan sosial di sekitar. Sigit mampu mengemas sesuatu yang ringan yang terkadang disepelakan menjadi karya seni visual yang lugas dan sangat komunikatif bagi publik yang mengakses. Terlebih pada tataran pemilihan tempat distribusinya yaitu di ruang-ruang publik menjadi kekuatannya dalam meminimalisir eksklusifitas seni yang hanya dapat diakses pada saat berada dalam ruang galeri.

Seni publik yang memiliki sifat sangat terbuka untuk diakses, menjadikan seni stensil yang memuat berbagai pemikiran kritis dari kreatornya, khususnya Digie Sigit dalam kasus ini dapat berdampak beragam terhadap reaksi publik saat berhadapan langsung dengan karya-karya stensil yang dibuatnya. Di samping hal tersebut, muatan fotografi yang juga kuat dalam seni stensil mampu memberikan pandangan baru terhadap para penikmat bahkan pelaku fotografi bahwa ternyata estetika dalam fotografi memiliki peluang yang sangat besar untuk dikembangkan hingga diaplikasikan dengan cara yang berbeda, dan tidak menutup kemungkinan dapat dieksplorasi dengan seni visual lain.

\section{KEPUSTAKAAN}

\section{Buku}

Bambaata. Afrika. Hip-Hop: Perlawanan dari Ghetto. Yogyakarta: Penerbit Alinea. 2005.

Barry, Syamsul. Jalan Seni Jalan Yogyakarta. Yogyakarta: Penerbit Studium. 2008.

Barthes, Roland. Elements of Semiology (trans. Annette Lavers \& Colin Smith). London: Jonathan Cape. 1967.

Image-Music-Text. London: Fontana. 1977.

$$
\text { Mythologies. New York: }
$$
Hill \& Wang. 1987.

MitosBudaya Massa : Semiotika atau Sosiologi Tanda, Simbol, dan Representasi. Yogyakarta: Penerbit Jalasutera. 2007

Budiman, Kris. Semiotika Visual. Yogyakarta : Jalasutera. 2011.

Danesi, Marcel. Pesan, Tanda, dan Makna. Yogyakarta : Jalasutera. 2010.

Fiske, John \& John Hartley. Reading Television. London: Methuen. 1978.

Hall, Stuart. 'Encoding/decoding'. In Centre for Contemporary Cultural Studies (Ed.). London: Hutchinson. 1980.

Irwandi, Muhamad Fajar Apriyanto Membaca Fotografi Potret. Yogyakarta: Penerbit Gama Media. 2012.

Manco, Tristan. Stencil Graffiti. United Kingdom: Thames \& Hudson. 2002.

Markowski, Gene. The Art of Photography: Image and Illusion. New Jersey: Prentice-Hall Inc. 1984.

Meleon, Lexy J. Metode Penelitian Kualitatif. Bandung : Rosda. 1995.

Saydak, Veronica Sarah. Street Art. Thesis of the Requirements for the Degree Master of Art. University of San Diego. 2011. 
Sigit, Digie. Tes.ti.mo.ni. Yogyakarta: Penerbit Graphic Victim. 2013.

Soedjono, Soeprapto. Pot-Pourri Fotografi. Jakarta: Penerbit Universitas Trisakti. 2007.

Sunardi, St. Semiotika Negativa. Yogyakarta: Kanal. 2002.

Waclawek, Anna. Graffiti And Street Art. New York: Thames \& Hudson (World of Art).NY.

\section{Pustaka Laman}

Google. "Kassian Cephas Pria di Balik Kelahiran Fotografi di Indonesia". Diakses pada: 7 Mei 2015

http://www.google.co.id/imgres?imgurl=http:// www.mobgenic.com/wp-content/ uploads/2013/05/Kassian-Cephas-02. jpg\&imgrefurl.

Google. "It's the Waiting that Kills You". Diakses pada 3 Mei 2015

http://www.google.co.id/imgres? imgurl=http: / / dailydujour.com / wp-content/uploads/2013/03/001$48 \times 48$-its-the-waiting-that-killsyou-

http: / / prancingthroughlife.com/wpcontent/uploads/2013/11/banksydreams_00349040.jpg. Diakses pada 01 Mei 2015 